\title{
Developing the Corporate Bond market- International Experience and Lessons for Vietnam Companies
}

\author{
Nguyen Duy Thinh ${ }^{1}$, Vu Ngoc Xuan ${ }^{2}$ \\ ${ }^{1}$ President, Hanoi Stock Exchange \\ Hoan Kiem Dist, Ha noi, Vietnam \\ Email: duythinh112 [AT] yahoo.com \\ ${ }^{2}$ Director Centre, Faculty of Economics, National Economics University \\ Hai Ba Trung Dist, Ha noi, Vietnam \\ Email: xuanvn [AT] neu.edu.vn
}

\begin{abstract}
Vietnam is in the process of developing into a middle-income country in the world. The widespread epidemic of covid-19 has had a negative impact on most Vietnam enterprises. However, the Vietnamese government's success in disease control has contributed to the recovery of business performance and efficiency. Vietnamese enterprises used to mobilize capital mainly through banking channels. In recent times, bonds are an important longterm capital mobilization tool for businesses, helping businesses reduce their dependence on commercial banks. This article mentions the development of the Vietnamese corporate bond market based on the experiences of several countries around the world.
\end{abstract}

Keywords--- business (Es), bonds (B), bond market (BM), corporate bonds (CB), credit rating (CR)

\section{EXPERIENCE IN DEVELOPING THE KOREAN CORPORATE BOND MARKET}

\subsection{History of establishment and development}

Korea's bond market was formed in the early 1950s when the Government issued Country Construction bonds to promote economic development and rebuild the country after the war. After that, businesses also started to issue bonds to attract capital (ADB, 2018). Before 1972, Korean corporate bonds (CBs) were only issued separately by a few large companies. In 1972, bond guarantees were introduced paving the way for the public issuance of CBs. All publicly issued CBs at that time were guaranteed by commercial banks (CBs), securities companies (SC) and financial institutions (FI). Until the mid-1980s, CBs were guaranteed to dominate the Korean CB market. The major investors of CB are investment funds and banks. The loosening of regulations on CBs led to a sharp increase in corporate bond mobilization (Hwang, 2016).

Credit rating $(C R)$ is an important criterion for investors in making financing decisions

The 1997 Asian financial crisis had a strong impact on the Korean CB market. During the crisis, a number of major issuers went bankrupt. This caused a deterioration in the asset quality of financial institutions that guaranteed bond payments and caused the Korean financial market to freeze. The Korean government tried to restructure the CB market with a series of market infrastructure changes.

Thereafter, the CB market has undergone significant structural changes after the crisis. Unsecured bonds gradually replace bonds guaranteed by major financial institutions. The CB market is also becoming more diversified with the introduction of asset-backed securities. This also increases the proportion of foreign investment in the CB market. In addition, the credit rating (CR) criteria of the bonds have also been changed, following a clearer and more transparent orientation. Therefore, the Korean CB market has gradually become a market with many high quality bonds. At the same time, the Government has also implemented many measures to facilitate the issuance of CBs with lower CR: introducing high-interest bond investment funds, launching the institutional investor market with enough conditions. sue and encourage liabilities collateralized by low-rated bonds. These measures have encouraged lower ranked companies to raise more money through the $\mathrm{CB}$ market.

\subsection{Market situation}

The Korean CB market can be considered as an effective long-term capital mobilization channel and continuously grows steadily over time. In 2000, the scale release CB South Korea reached 292 trillion KRW only has increased more than 4 times, reaching more than 1,200 trillion KRW in 2017. 
The trading size CB Korean growth also amazing in the past. Basically, the transaction size on the secondary market tends to increase in the period 2000 - 2017. However, it can be seen that 2003 - 2007 was the period when the CB market reached a low level, the transaction size translation is only between 50,000 - 60,000 billion KRW. In contrast, in 2013 , the transaction market peaked at nearly 190,000 billion KRW. The reason is that during this period, the Korean Government has implemented a number of policies to increase market transparency, promote bond transactions.

\subsection{Major policies}

Korea has issued a lot of policies to increase transparency and promote growth in the CB market. Most notably are the following policies: bond pricing regime; measures by the Ministry of Finance and Economy (MOFE) to develop the bond market in February 2000 and November 2005; measure by the Financial Supervisory Commission to boost the bond market in December 2006; measures to improve the primary bond market in October 2011 aimed at developing investment banks; plans to normalize the bond market in 2012.

After the financial crisischínhAsia, South Korea has introduced the system of valuation at market prices, and gradually expand the scope of application. The application of this system in determining CB prices is aimed at increasing the transparency of bond prices. Unlike stocks, each bond issue has characteristics independent from each other even when the same issuer. Therefore, not all bonds are traded on the market. Therefore, it is difficult to determine bond prices based on outstanding bonds. These features are incorporated into the market pricing system; Accordingly, bond valuators are set up to estimate fair value of the bonds and publicize bond prices. In 1999, Korea established 3 bond valuation agencies, which function in bond valuation and provide bond price information services. This system has contributed to making the CB market more transparent and the secondary market more efficient (Hwang, 2016).

In 2000, MOFE issued many policies focusing on improving the market structure: (i) streamlining the bond issuance process; (ii) expanding the role of financial intermediaries in bond transactions; (iii) improving bond issuance and trading structure; (iv) allow the establishment of the brokerage system and the bond brokerage firms; (v) referral of contract repurchase transactions. Last two policies were issued to increase the size of bond trading. In addition, the information disclosure system has been adopted to ensure greater transparency in the bond market. According to the disclosure mode, securities companies are required to report bond trading data within thirty minutes of making a transaction with the Financial Investments Association, after which, they must publish the delivery data. Instant translation through its terminal. These disclosure requirements increase transparency in decentralized bond trading (OTC) and increase efficiency in the secondary market.

In 2005, MOFE licensed bond management and insurance business underwriting firms. In 2009, the Enterprise Law was revised to introduce a debt trust system. For guarantee insurance, the Korea Credit Guarantee Fund Law was amended to allow the Korea Credit Guarantee Fund to guarantee on-time principal and interest payments for bonds. However, these policies are not really effective in the guaranteed bond market.

In October 2011, a policy was implemented to improve the primary market. The Enterprise Law sets out the procedures for issuance. In 2011, this Law was amended, allowing businesses to be more proactive in issuing bonds. The amended Enterprise Law in 2011 applies the mechanism of establishing a bond management company to improve investor protection. Banks, SC and other FIs in the market can act as a bond regulator. In addition, the 2011 Law on Enterprises also loosened restrictions on bond issuance and enhanced investor protection, which brought improvements in institutions to CBs.

When the CB market tightened in 2013, the Korean government announced plans to normalize the entry market by providing tax benefits to high-yield bond investment funds and promoting investment funds. CB. At the same time, the Korean government also enacted the Law on financial investment services and capital markets. This Law provides for the scope of activities related to information disclosed by issuers (issuers), regulations on credit ratings, regulations, procedures for licensing procedures, registration instructions, and information. periodical announcement, investment licenses, tax regulations, regulations on handling violations of businesses and investors. The application of the Law on financial investment services and capital markets aims to regulate and adjust the contents of procedures for registration of issuance for enterprises, and guide enterprises to fulfill their obligation to provide information. information during release and post-release licensing. At the same time, this Law also contains regulations and sanctions to prevent activities related to the provision of false information, abuse, self-seeking of enterprises, and protection of investment organizations.

\subsection{Historical background}

\section{EXPERIENCE IN DEVELOPING THE THAI CORPORATE BOND MARKET}

Before the Asian economic crisis in 1997, CB acted as the main financial intermediary, the main source of capital for businesses. The size of Thailand's CB market at that time was quite small and undeveloped (ADB, 2012). Ruengvirayudh and Panyanul (2006) argue that nine consecutive years of fiscal surpluses between 1988 and 1996 create no incentive for the government to undertake frequent and significant problems of government bonds. Limited supply of government bonds has hampered the development of the risk-free standard, which is the basis for bond issuers to value their bonds, thus hindering the development of the CB market. . The 1997 crisis was exacerbated by the imbalance in the structure and operation of the Thai financial market. With limited financing options in bank loans, businesses in Thailand face a 
serious liquidity crisis as the banking industry ceases lending in the midst of poor lending rates. high, thus, accelerating the economic recession. The Thai government made extra efforts to boost the domestic bond market by adopting a number of measures, including legal amendments and institutional reform (Srinopnikom, 2011).

\subsection{Market situation}

Due to the application of certain measures by the Thai Government, the Thai CB market started to develop steadily after the financial crisis in 1997. Scale of CB issuance in the primary market Gradually increasing, from more than 140 billion THB in 1997 to more than 20 times, reaching 3,083 billion THB in 2017. In the

first phase after the financial crisis, the number of large enterprises with good potential could meet the The strict requirements of $\mathrm{CR}$ agencies are not much, leading to higher costs of issuing CBs than for bank loans (Ruengvirayudh and Panyanul, 2006). Therefore, in the period 1997 - 2002, only a few firms were able to issue bonds.

On the secondary market, the size of the bond transaction is not stable for a relatively long time. From 2011 up to now, the $\mathrm{CB}$ transaction size tends to grow relatively stable and has the best growth rate. Transaction size reached 51 billion THB in 2011 and increased to 269 billion THB in 2017. However, compared with the current size of bonds, the transaction size of CB Thailand is still very small.

\subsection{The main policies}

Bank of Thailand (BoT) oversees the operations of banking and financial businesses while the Securities and Exchange Commission (SEC) oversees the primary and secondary markets for business. stock. Issuance and offering of securities are governed by the Securities and Exchange Act of 1992.

The Thai Bond Market Association (BMA), as regulated by the SEC, acts as a self-regulatory body with Market surveillance powers cooperate with the inspection and enforcement functions of the SEC. The BMA is responsible for establishing market conventions, best practices, and codes of conduct. SEC regulations stipulate that all agent transactions must be reported to BMA in a timely manner, currently at 30 minutes of transaction, in order for BMA to disseminate market information on its website.

To promote a degree of professionalism and ensure fairness and order in the bond market, SEC regulations require all bond traders to register with the BMA. To apply, the investor must meet the set criteria and pass the registered examination managed by BMA. The BMA will be responsible for ensuring that, the trading activities of registered investors comply with the Ethics and Rules and Behavior established for the bond market.

Businesses that issue bonds through a public offering must obtain approval from the SEC. Most companies usually appoint financial advisor, underwriter and sales agent to help them with underwriting processes issues while applying for SEC approval. The Financial Advisor will assist the issuer in obtaining issuance approval, including providing certain data and information to the CR process. Financial advisors and underwriters are usually the same company, most of whom are CBs. In the case of a public offering, there is no limit to the number of issues available to an issuer. However, CR must be made prior to release. Issuers are also required to register to issue with BMA within one month of issuance.

In the case of a private placement, the above requirements will be canceled if the enterprise can satisfy one of the following conditions: (i) there are less than ten investors participating in the issue; (ii) the total issue value is less than 100 million THB; (iii) issue bonds sold to creditors for corporate restructuring proposals; or (iv) the SEC has issued a special waiver. Businesses will have fewer obligations than with a public offer, such as CR exemptions. However, the documents related to the issuance cannot be made publicly available, but only to specific investors. The intermediaries in the primary market are agents, with the function of distributing bonds issued from the issuer to investors. Usually, dealers buy newly issued bonds and resell them to the public. In the event that the value of the issue is very large, the dealer will set up an organization to underwrite the issue.

Activities on the secondary market include OTC and concentration. Before the establishment of the E-bond Exchange, bonds were traded through the OTC market, which was only allowed for institutional investors. As a result, retail investors were previously excluded from the OTC market. The creation of an Electronic Bond Exchange, which has an electronic trading platform as a major feature, has introduced investors to an additional investment tool and diversified benefits. Under the Securities and Exchange Act, investors are required to submit their quotes through authorized agents to buy or trade bonds in the Bond E-Commerce Exchange. For the OTC market, the stock exchange system, introduced by the Stock Exchange of Thailand on March 1, 2006 as a platform for agency trading and wholesale client trading. . On this system, the customer cannot post his bid to quote, but is allowed to submit quote request to multiple agents at the same time and can conduct offline negotiations. 


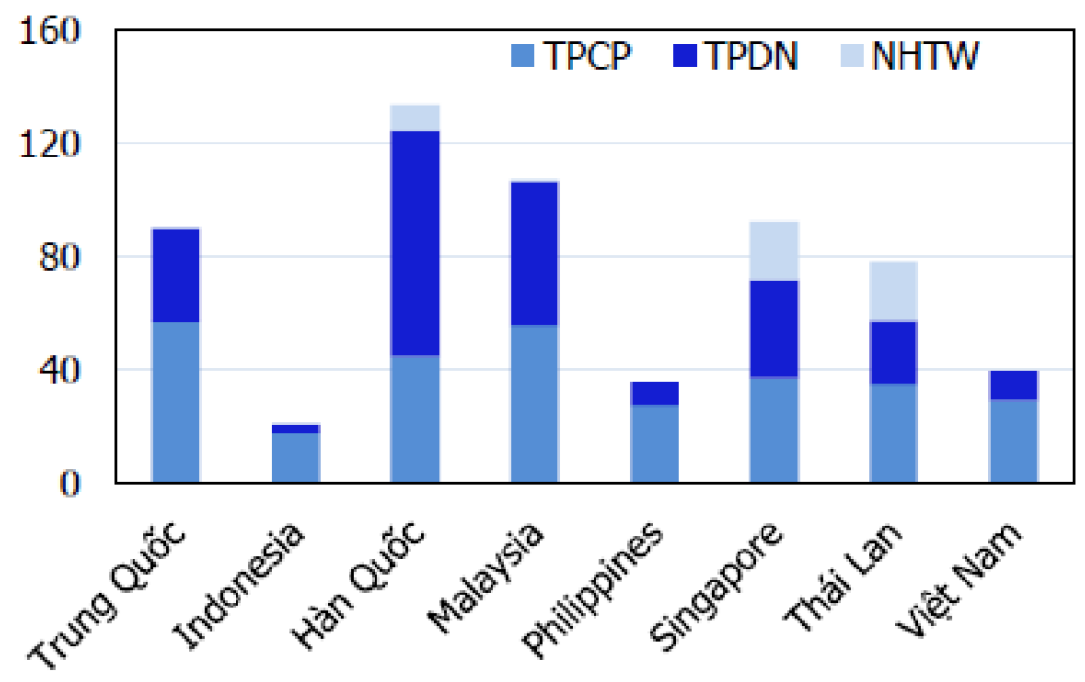

Figure 1. Size of bond markets in the region (\%GDP)

(Source: Asian Development Bank - ADB)

\section{CURRENT SITUATION OF VIETNAM CORPARATE BOND ISSUANCE}

The corporate bond market is a capital mobilization channel for enterprises to develop production and business. Corporate bonds are issued in 2 forms, including (i) issued to the public (ii) privately issued.

- For individual corporate bonds:

+ Issuing purpose: The enterprise issues bonds to

(i) invest in programs and projects

(ii) (ii) Increases the scale of working capital (iii) Debt restructuring.

+ Regarding the method of issuance: corporate bonds are issued in one of three modes: bidding, guarantee; retail (only for issuers that are credit institutions).

- For corporate bonds to be issued to the public, offering conditions and registration documents shall comply with the Law on Securities, Decree 58/2012/ND-CP guiding the implementation of a number of articles. Law on Securities and the Law amending and supplementing a number of articles of the Law on Securities and Decree 60/2014/ND-CP amending and supplementing a number of articles of Decree No. 58/2012 / ND-CP. For the CB market, the legal corridor has been gradually added and completed, Decree 81 was issued and comes into effect from September 1, 2020 with basic amendments to issuance conditions and limitations. the scale of the private placement is suitable to the capital scale of the enterprise, ...

Since the effective date of Decree 81, there have been some strong fluctuations in the issuance of corporate bonds in both issuance size and period. issuance deadline and release structure. Corporate bond issuance increased strongly in the first two months of Q3 before cooling down in September when Decree 81 came into effect. The total value of corporate bonds successfully mobilized in the first 9 months of the year reached over VND 343 trillion, up 83\% over the same period in 2019. The average term of bonds issued in the period is 4.1 years. while the average interest rate is $9.3 \%$ / year. Bonds of the real estate group accounted for $48 \%$ of the issue, followed by the banking group with $29 \%$.

Regarding the issuance scale, due to stricter regulations on issuing conditions, the situation of CB issuance has a strong downward trend. Regarding issuance term, it shows that enterprises tend to focus on medium and long term terms compared to many short-term issuance as before.

Regarding the issuance structure, there is a change in the share of issuance among business groups. Specifically, the group with the largest proportion of $\mathrm{CB}$ issuance moved from real estate businesses to the credit institution sector in September and October 2020.

Decree 81/2020 / ND - CP coming into effect from September 2020 has significantly reduced the amount of bonds issued in the last month of the third quarter. However, the previous August saw a huge amount of bonds issued, up to nearly 95 trillion. VND, more than 3 times higher than the same period as businesses took advantage of the last time before new regulations tightened bond issuance conditions. As a result, in the third quarter, there were 167.1 trillion dong of CBs issued, an increase of about $97 \%$ compared to the third quarter of 2019 , of which $\$ 75$ million of bonds were issued to the international market.

In the first 9 months of 2020, Vietnamese businesses issued 343.3 trillion CBs, of which about $95 \%$ were through private channels. The weighted average maturity of the bonds is 4.1 years, while the interest rate is $9.3 \% /$ year. The Covid-19 epidemic had 
a profound effect on the whole economy, and business activities were stagnant. Credit growth is also quite weak partly because of tight loan conditions, so businesses turn to issuing CBs with more breathing conditions. The CB portfolio at many banks has increased dramatically this year.

On July 28, HNX issued Document No. 384/QD-SGDHN on the Regulation on operation of the corporate bond information website. Accordingly, some information will no longer be published to ensure confidentiality such as interest rates and buyers. Thus, interest rate trends are no longer easily identifiable.

The Real Estate group is the leading industry in bond issuance in Q3 and 9 months. In the third quarter alone, this group issued 80 trillion dong $\mathrm{CB}$, and from the beginning of the year, the amount of bonds mobilized was 163.3 trillion dong, accounting for $48 \%$ of the total number of bonds issued. The weighted average interest rate of real estate bonds is $10.5 \%$ / year while the average term is 3.6 years.

The second group in terms of volume of bonds issued are banks. In the last 3 months, banks have issued 50.6 trillion dong of bonds. In total, in the first 9 months of the year, there were 19 different banks mobilizing 99 trillion dong of bonds, the rate of $29 \%$. In addition to familiar domestic banks, the list of issuers appearing for the first time is an international bank, HSBC Vietnam. Weighted average maturity of bank bonds is 4.7 years. The average interest rate is $6.6 \%$ / year.

This year, enterprises in the Electricity / Water sector also actively mobilized capital through the bond channel with 26.2 trillion VND in 9 months. The typical feature of this group bond is the long term, 7-year average, much higher than the average because power plants need a longer time to pay back their capital. Because of the long term, the interest rate is also relatively high, about $10.5 \%$ / year.

Securities companies have also increased bond mobilization during the time to supplement capital for margin lending business, in the context that the stock market is recovering from the bottom of March. In 9 months, securities companies CB issued 6.2 trillion dong, of which more than half were issued in the third quarter. The term and interest rate of bonds are also not large, averaging just 2 years and $8.8 \%$ / year, respectively. .

Other businesses issued 48.6 trillion dong of bonds since the beginning of the year, mainly in the construction, manufacturing and retail sectors. Bonds have a 3-year term on average and yield $10 \%$ per year, of which construction / infrastructure and other finance groups have shorter maturities but higher interest rates than the rest.

Currently, the State Bank is drafting a Circular regulating credit institutions and foreign bank branches to buy and sell corporate bonds. In particular, there is a regulation that CBs can only buy CBs when they have a bad debt ratio of less than $3 \%$ according to the audited financial statements of the preceding year. In addition, CBs are not allowed to buy bonds of issuers that have incurred bad debts within the last 12 months. In particular, CBs are not allowed to buy corporate bonds for the purpose of contributing capital or buying shares in other businesses. If this regulation is passed, the market situation for CBs may continue to change as currently CB buyers are mainly banks.

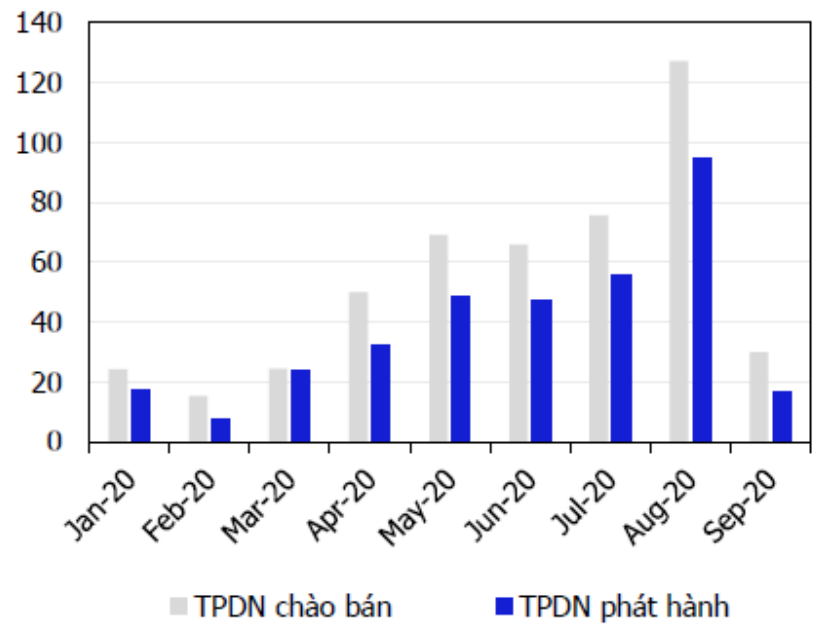

Figure 2. Volume of corporate bonds successfully offered for sale and issued (trillion VND)

(Source: HNX, FiinPro, MBS Research compiled) 


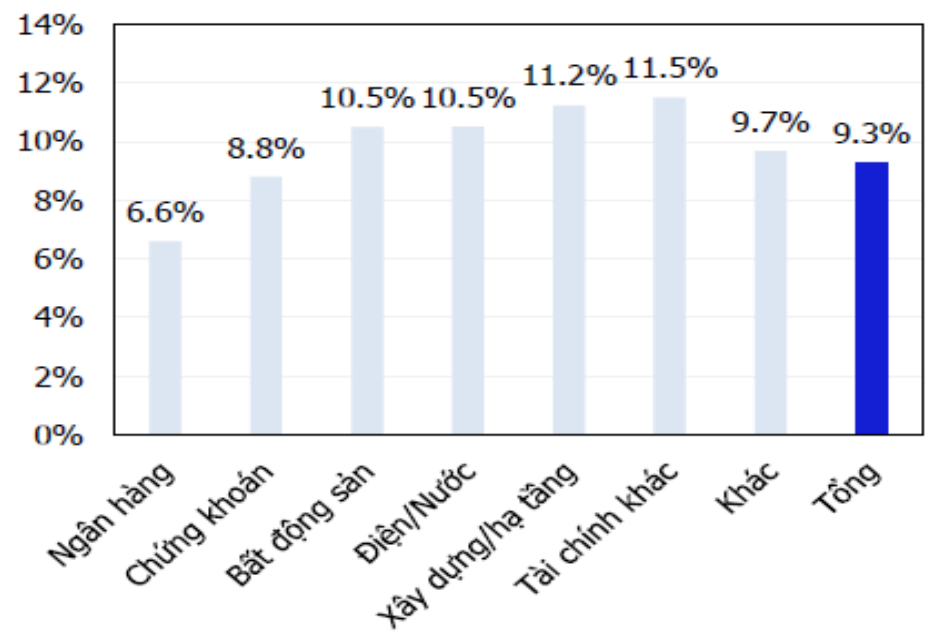

Figure 3. Average coupon rate of bonds issued in 2020 by business group Enterprise (\%/year) (Source: HNX, FiinPro, MBS Research compiled)

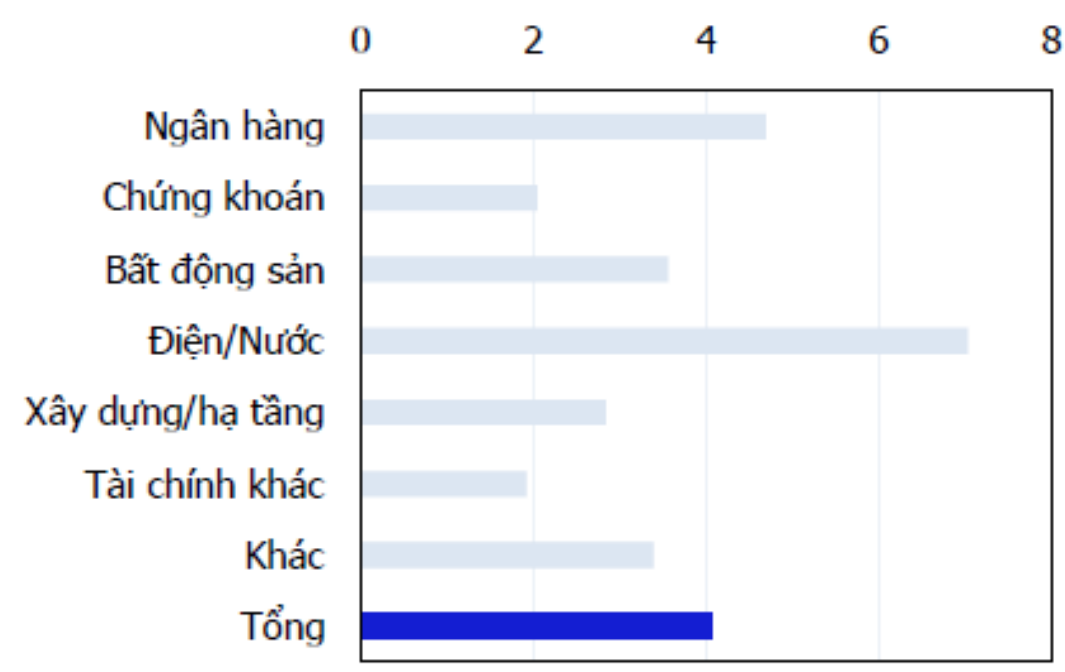

Figure 4. Average maturity of bonds issued in 2020 by business group (years) (Source: HNX, FiinPro, MBS Research compiled) 


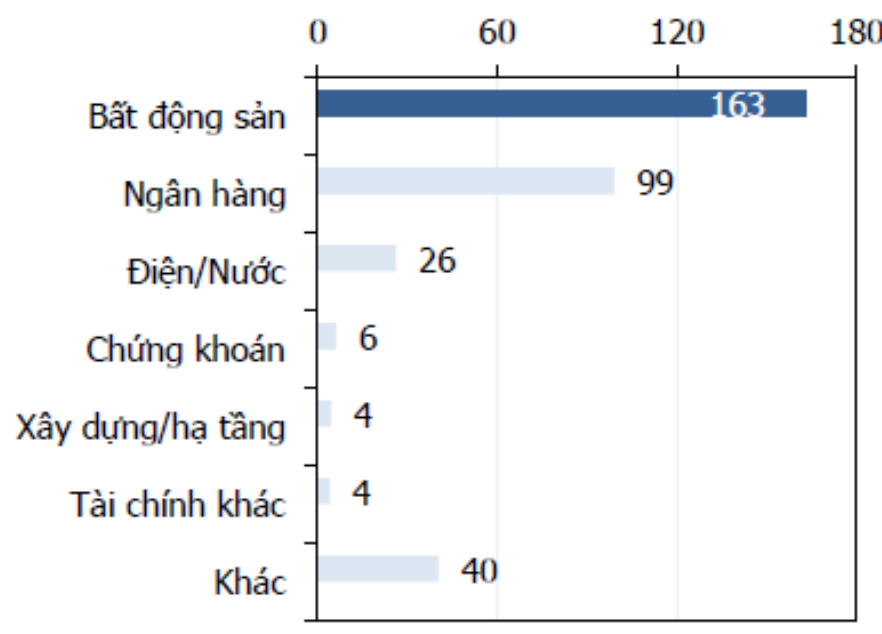

Figure 5. Industry group structure of issuing CB from the beginning of 2020 (trillion VND) (Source: HNX, FiinPro, MBS Research compiled)

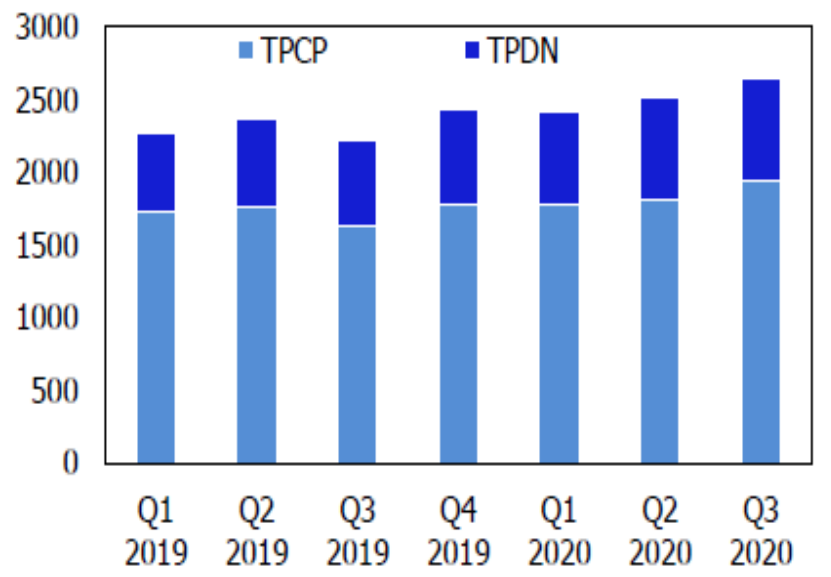

Figure 6. Outstanding debt in the Vietnamese bond market in the quarters (trillion VND) (Source: HNX, FiinPro, MBS Research compiled)

\section{LESSONS LEARNED FOR VIETNAM CORPORATE BOND MARKET}

Firstly,compared with government bonds, the risk of CB is usually higher. This leads to lower issuance capacity and liquidity of CBs. In order for investors to have a solid basis in their decision making, it is essential to ensure transparency of information. Information about the credit rating, price, ... of the bonds should be widely publicized, ensuring the accessibility of investors. In Vietnam, access to information about CBs is still very limited and difficult. Therefore, it is necessary to have a main focal point that synthesizes all information about CBs. This helps to concentrate information, facilitate the access and exploitation of information by interested parties. Here will perform to synthesize, classify and process this information in a reasonable way. Some information may need to be made publicly available in easily accessible mass media. Some information may be provided upon request by investors or organizations or individuals in need.

Second, information is the primary factor that plays an important role in the decision making of market participants. In Vietnam today, in the law on bond issuance, there are regulations that the businesses issuing bonds must disclose basic information about businesses and bonds to investors, to the House Securities Commission. country, Ministry of Finance. However, the information was not made public. Finding or accessing information about corporate bond issuance and trading, especially private placement, is very difficult. Furthermore, private issuers are not allowed to disclose information on the Internet to invite investors to participate. This is the difference with many developed CB markets when countries try to make this information transparent. Therefore, it is necessary to add regulations on information disclosure of bond issuers, including both private and public issues. These businesses need to proactively 
notify all relevant information about bonds to regulators and investors. For a public issuance, information should be publicly disclosed before and after it is published on the website of the issuer and the Stock Exchange. For a private release, information should be made publicly available immediately after release. Adequate and transparent information also helps CR businesses have a reliable basis in performing business ratings and bonds according to international standards, facilitating increased liquidity and market size.

Third, CB credit rating is an important criterion for investors in making funding decisions. In countries with developed CB markets, business rating in general and bond rating in particular are mandatory requirements when issuing bonds. This rating is performed by professional credit rating agencies. In Vietnam, there is currently no bond rating activity. Currently, Saigon Phat Thinh Rating Joint Stock Company is the next Vietnamese organization licensed to operate in this field. However, the operation of this business is still quite fuzzy, failing to meet the information requirements of investors in the market. The government may issue a regulation that businesses are required to carry out $\mathrm{CR}$ bonds prior to issuance. The $\mathrm{CR}$ needs to be done by reputable $\mathrm{CR}$ organizations that perform the ranking methodically, according to international standards. In addition, this will also create favorable conditions for bonds of Vietnamese businesses to be listed in international markets.

Fourth, enhancing the publicity and transparency in corporate bond issuance activities at the Hanoi Stock Exchange (HNX). For the CB market, the legal framework continues to be improved to help the market to have more sustainable development steps, which will have a significant impact on the bond market, typically the Securities Law 2019 takes effect from the date of 1-1-2021. In order to enhance the transparency in the market, HNX needs to put the $\mathrm{CB}$ information site into official operation, which will help investors access the information faster, more easily and comprehensively, in addition, the website needs to be built. built and developed according to international standards such as the United States, Korea ... The CB information site is organized to provide investors with information about corporate bonds issued separately by enterprises according to regulations. in Decree 163/2018 / ND-CP.

Fifth, the CB information site needs to disclose the basic contents of all CBs of individual issuers, to serve the needs of all information inquiries. object of investors, as well as for the statistical work, reporting on the individualissuance CBs. In addition, it is necessary to conduct research on the $\mathrm{CB}$ secondary transaction market, complete the legal framework for the organization of transactions for private issuance CB transactions.

\section{REFERENCES}

1. Ari, K. \& Fredrik, S. (2004), “The Internationalization of Vietnamese SMEs, Stockholm School of Economics", Asian Economic Papers, Vol.4, No.1, 12-39.

2. Baard, VC \& Van den Berg, A. (2004), "Interactive Information Consulting System for South African Small Businesses", South African Journal of Information Management, Vol.6, No.2, 39-50.

3. Fausto, HT, Jose, A., Pagan and Julia, P. (2013), 'Star up capital. Microenterprises and technical eficiency in Mexico', Review of development Economics, 9, 434-447.

4. Henrik Hansen, John Rand \& Finn, T. (2002) "SME Growth and Survival in Vietnam: Did Direct Government Support Matter?", accessed http://www.vnep.org.vn

5. Jabri, A. and Brahim, M. (2015). Institutional determinants of foreign direct investment in MENA region: Panel co- integration analysis. Journal of Applied Business Research (JABR), 31(5),2001-2012. https://doi.org/10.19030/jabr.v31i5.9417

6. Jabri, A., Guesmi, K., and Abid, I. (2013). Determinants of foreign direct investment in MENA region: Panel co-integration analysis. The Journal of Applied Business Research, 29(4), 1103-1109. https://doi.org/10.19030/jabr.v29i4.7976

7. Jensen, NM (2003). Democratic governance and multinational corporations: Political regimes and inflows of foreign direct investment. International Organization, 57(3), 587-616. https://doi.org/10.1017/S0020818303573040

8. Jouili, T. (2018). Determinants of foreign investment in maritime nations. International Journal of Advanced and Applied Sciences, 5(5), 43-47. https://doi.org/10.21833/ijaas.2018.05.006

9. K. Salman \& D. Yazdanfar (2012), "Profitability in Swedish SME firms: A quantile regression approach", International Business Research, vol. 5, no. 8, 94-106;

10. Kumar, N. (1994). Determinants of export orientation of foreign production by US multinationals: An intercountry analysis. Journal of International Business Studies, 25(1), 141-156. https://doi.org/10.1057/palgrave.jibs.8490196

11. Kwiatkowski, D., Phillips, PC, Schmidt, P., and Shin, Y. (1992). Testing the null hypothesis of stationary against the alternative of a unit root: How sure are we that economic time series have a unit root? Journal of Econometrics, 54(1-3), 159-178. https://doi.org/10.1016/0304-4076(92)90104-Y

12. Lei, HS, Chen, YS (2011), The right tree for the right bird: Location choice decision of Taiwanese firms' FDI in China and Vietnam International Business Review, Elsevier, $20 \quad$ (3), 338-352. https://doi.org/10.1016/j.ibusrev.2010.10.002 
13. Loree, DW and Guisinger, SE (1995). Policy and non-policy determinants of US equity foreign direct investment. Journal of International Business $\quad$ Studies, 281-299. https://doi.org/10.1057/palgrave.jibs.8490174

14. Louail, B. (2019). Determinants of foreign direct investment in Arab countries during 1970-2016. International Journal of Advanced and Applied Sciences, 6(3), 102-110. https://doi.org/10.21833/ijaas.2019.03.015

15. Mehari and T. Aemiro (2013), "Firm specific factors that determine insurance companies' performance in Ethiopia", European Scientific Journal, vol. 9, no.10, 245-255.

16. Mina, W. (2007). The location determinants of FDI in the GCC countries. Journal of Multinational Financial Management, 17(4), 336-348. https://doi.org/10.1016/j.mulfin.2007.02.002

17. Mina, WM (2012). The institutional reforms debate and FDI flows to the MENA region: The "best" ensemble. World Development, 40(9), 1798-1809. https://doi.org/10.1016/j.worlddev.2012.04.026

18. Moosa, IA (2009). The determinants of foreign direct investment in MENA countries: An extreme bounds analysis. Applied Economics Letters, 16(15), 1559-1563. https://doi.org/10.1080/13504850701578819

19. Mssimo, G. and Colombo (2015), 'Start up size- The role of external financing', Economic Letters, 88, $107-121$.

20. Nguyen, HA et al (2020), Impact of Working Capital Management on Firm's Profitability: Empirical Evidence From Vietnam. Journal of Asian Finance, Economics and Business, 7(3), $115-125$. https://doi.org/10.13106/jafeb.2020.vol7.no3.115

21. Nguyen, TNL, Nguyen, VC, (2020). The Determinants of Profitability in Listed Enterprises: A Study from Vietnamese Stock Exchange. Journal of Asian Finance, Economics and Business, 7(1), 47-58. https://doi.org/10.13106/jafeb.2020.vol7.no1.47

22. Nnadi, M. and Soobaroyen, T. (2015). International financial reporting standards and foreign direct investment: The case of Africa. Advances in Accounting, 31(2), 228-238. https://doi.org/10.1016/j.adiac.2015.09.007

23. Panco, R., and Korn, H (1999), "Understanding Factors of Organizational Mortality: Considering Alternatives to Firm Failure", accessed http://www.eaom.org

24. Parker, S. and Phan, VQ and Nguyen, NA (2005): Has the US-Vietnam Bilateral Trade Agreement Led to Higher FDI into Vietnam? International Journal of Applied Economics, 2 (2), 199-223.

25. Pesaran, MH (1997). The role of economic theory in modelling the long run. The Economic Journal, 107(440), 178-191. https://doi.org/10.1111/1468-0297.00151

26. Pesaran, MH and Shin, Y. (1998). An autoregressive distributed-lag modelling approach to cointegration analysis. Econometric Society Monographs, 31, 371-413. https://doi.org/10.1017/CCOL521633230.011

27. Pesaran, MH, Shin, Y., and Smith, RP (1999). Pooled mean group estimation of dynamic heterogeneous panels. Journal of the American Statistical Association, 94(446), 621-634. https://doi.org/10.1080/01621459.1999.10474156

28. Pesaran, MH, Shin, Y., and Smith, RJ (2001). Bounds testing approaches to the analysis of level relationships. Journal of Applied Econometrics, 16(3), 289-326. https://doi.org/10.1002/jae.616

29. Pricope, CF (2017). The implications of IFRS adoption on foreign direct investment in poor countries. The Audit Financial Journal, 15(146), 218-218. https://doi.org/10.20869/AUDITF/2017/146/218

30. Ramasamy (2005), "Firm size, ownership and performance in the Malaysian palm oil industry", Asian Academy of Management Journal of Accounting and Finance, vol. 1, pp. 81-104;

31. Rogmans, T. (2013). Location and operation mode decision making in the Middle East: A case study approach. Journal of Strategy and Management, 6(2),190-206. https://doi.org/10.1108/17554251311322440

32. Stierwald (2009), "Determinants of firm profitability-The effect of productivity and its persistence," Melbourne Institute of Applied Economic and Social Research, The University of Melbourne;

33. Tran, TQ (2009). Sudden Surge in FDI and Infrastructure Bottlenecks: The Case in Vietnam. ASEAN Economic Bulletin 26(1), 58-76. https://www.muse.jhu.edu/article/266539.

34. Vijayakumar (2011), "An empirical study of firm structure and profitability relationship: The case Of Indian automobile firms," International Journal of Research in Commerce and Management, vol. 1, no. 2, 100-108;

35. Vijayakumar (2011), "The determinant of profitability: An empirical investigation using Indian automobile industry," International Journal of Research in Commerce and Management, vol. 2, no. 1, 58-64;

36. Xuan, VN (2020), Factors affecting foreign direct investment: Evidence at foreign technology enterprises in Vietnam. International Journal of Advanced and Applied Science, 07(4), 21-28. https://doi.org/10.21833/ijaas.2020.04.004

37. Xuan, VN (2020), Determinants of Investment Capital Size: A Case of Small and Medium Sized Enterprises in Vietnam. Journal of Asian Finance Economics and Business. https://doi.org/10.13106/jafeb.2020.vol7.no6.019 